\title{
Hõimlane verejõe tagant: Saami muinaslood tootempõhjapõdrast. I
}

\section{$\underline{\text { Enn Ernits }}$}

\section{Uurimuse taustast}

Enam kui aastakümne eest lugesin Vladimir Tsharnoluski kogutud ja vene keeles üllitatud "Saami muinasjutte" (Tsharnoluski 1962), mis tundusid niivõrd omapärastena, et otsustasin paremiku eesti keelde tõlkida. Koostasin paari teose põhjal ümberpanemist väärivate muinaslugude loetelu ja tõlkisin isegi paar juttu. Paraku jäi toona kõik soiku.

Uut innustust sain Eesti Muinastaideseltsi tarmukalt kaasliikmelt, ajaloolaselt Eero Autiolt, kes hakkas Koola-reisil nähtud Põõnne (vene keeles Ponoi) kaljuraiendite mõjul soomendama ja tõlgendama V. Tsharnoluski avaldatud müüte saami ehk lapi tootempõhjapõdra kohta (Autio 1990).

Naasin V. Tsharnoluski teoste juurde, valides sedapuhku tõlkimiseks ja kommenteerimiseks reisikirjana avaldatud "Legendi inimpõdrast Meandashist" (Tsharnoluski 1965). Seejärel kogusin ja süstematiseerisin asjaomast ainestikku Emakeele Seltsis 1993. aasta kevadel peetud ettekande jaoks.

E. Autioga arenes asjalik kirjavahetus V. Tsharnoluski tekstis esinevate ebakohtade selgitamiseks. Viibisin 1993. aasta suvel esimese rahvusvahelise soome-ugri ajaloo kongressi järel tema linnakodus Varkausis, kus jätkasime mitme päeva vältel saami probleemide, eriti Meandashiteema arutelu. Helsingi Ülikooli raamatukogus aitas E. Autio mul leida lisa kirjandusele, mis Tartus puudub, ja seda kopeerida. Sama aasta jõuludeks oli minu töölaual äsjailmunud raamat koos autoripühendusega (Autio 1993). Avaldan siinkohal talle siirast tänu abi eest! Tänan ka välismaal ilmunud Meandashi-lugude kserokoopiate hankimise eest Mare Kõivat ja Andres Kuperjanovit!

V. Tsharnoluski reisikiri jääb esialgu ootama sobivamat ilmumisaega. Katkendeid sellest ja müüditekste kasutan esialgu käesolevas uurimuses.

Saamid ehk laplased elavad Norra, Rootsi, Soome ja Venemaa põhjaosas, mida kutsutakse Lapimaaks * vt kaarti. Saami keelte arv kõigub eri uurijate arvates 6 ja 8 või isegi 10 vahel. Eristatakse lääne- ja idarühma. Meie uurimuse seisukohast pakuvad huvi Koola poolsaarel elavad idarühma keeli kõnelevad saamid. 1989. aasta rahvaloendus registreeris seal kõigest 1900 laplast, kellest vaid veidi alla poole (49,2 \%) valdab emakeelt. Koola poolsaarel räägitakse kolme saami keelt, nimelt

1. kolta keelt (kasutatakse ka Soomes ja Norras),

2. turja keelt ning

3. kildini keelt, mis jaguneb kildini ja akkala murdeks.

Koltad elavad Koola poolsaare loode-, turjalased kirde- ja kagu- ning kildinid idaosa asulates. Nende saami-, soome ja venekeelsed nimetused on sageli üpris erinevad. Alljärgnevalt esitan need 
Itkoneni 1858. aasta väljaande järgi (vt tabel 1); käesoleva kirjutise autor eelistab üldiselt saamikeelseid nimetusi.

Tabel 1

Koola asulate saami-, soome ja venekeelsed nimetused

\begin{tabular}{|l|l|l|l|}
\hline Keel & Saami nimetus & Soome vaste & Vene vaste \\
\hline Kolta & Keeunges & Boris-Gleb & Boris-Gleb \\
\hline$"$ & Pattshiesijd & Paatsjoki & Pazreka \\
\hline$"$ & Peattsemsijd & Petsamo & Petshenga \\
\hline$"$ & Nuohtjaur & Nuortijärvi & Notozero \\
\hline$"$ & Muödkesijd & Muotka & Motka \\
\hline Turja & Sarvessijt & Hirvasjärvi & Girvasozero \\
\hline$"$ & Jovkõj & Jokanga & Jokanga \\
\hline$"$ & Lõmbes & Lumbovsk & Lumbovsk \\
\hline$"$ & Põõnne & Ponoi & Ponoi \\
\hline$"$ & Kintush & Kamensk & Kamensk \\
\hline Kildini murre & Kildsijt & Sosnovka & Sosnovka \\
\hline$"$ & Kordagk & Kildin & Kildin \\
\hline$"$ & Lujaur & Luujärvi & Lovozero \\
\hline$"$ & Maselga, Maaselg & Maaselkä & Masel'ga \\
\hline$"$ & Nuörtsaame & Semiostrovsk & Semiostrovsk \\
\hline Akkala murre & Tshugksuöl & Jokostrov & Jokostrov \\
\hline$"$ & Aahkkel & Akkala & Babino \\
\hline \hline
\end{tabular}

$* * * * *$

Koola poolsaare saami kultuuris säilisid ürgsed jooned suhteliselt kaua, nende seas ka ulukpõhjapõdra kultus, millest kõnelebki käesolev uurimus.

Heidame põgusa pilgu koguteose "Loomade elu" imetajate köitele (LE 1987: 354 jj), millest võime lugeda, et põhjapõder (Rangifer tarandus) on suhteliselt pika kaela ja kerega, kuid lühikeste jalgadega hirvlane. See on keskmiselt üle 2 meetri pikkune ja 100-220 kilogrammi raskune tundraja taigaelanik. Erinevalt teistest hirvlastest on sellel sarved nii isas- kui ka emasloomadel. Maailmas on ühtekokku 1,5 miljonit kodustamata ehk metsikut põhjapõtra, kes kauges minevikus elasid ka Eesti aladel. Koolas leidub nii metsikuid kui ka kodustatud põhjapõtru. 


\section{Kes on Meandash?}

V. Tsharnoluski meenutas unustamatuid Koola-päevi:

Sõidame koos Jestrati-taadiga kahekesi Lasmitrai meeskonna juurde. Oleme inimasulatest kaugel, paljal kaljusel Keiva (*1) mäenõlval. Lõpmatust lumest valge, kergelt künklik, tuultest, vihmadest ja vooluvetest uuristatud ürgne ja sammaldunud, turbamätaste ja samblikega kaetud maa puhkab hangede all. Lumevaiba alt kikitavad välja kaks massiivset kaljut; silman graniiti, samblikest halli, ürgset - sellisena oli ta emakese maa põues sündinud.

Kogu maa on põhjapõder ning Keiva ta turi (Tsharnoluski 1965: 77).

Kirjeldus vastab vanale saami kujutelmale. Ka päike ja Suur Vanker olid nende ettekujutustes põhjapõdrad, toiduallikaks aga kas metsik või kodustatud põhjapõder. Ennastki pidasid nad põhjapõdra järglasteks. Põhjapõder oli muiste saamide kõiksus.

Koola saamide usundis kõneldakse kuldsarvedega tootempõhjapõdrast Meandashist, mõnel pool ka Mientushist. Tootem on loom, vahel ka taim või loodusnähtus, mida muinasaja inimene pidas oma esivanemaks. Osa saame arvas end põlvnevat põhjapõdrast. Selleks, et hõimu käsi hästi käiks, pidi iga liige oma esivanemaga hästi läbi saama. Peeti kinni tabudest ehk keeldudest. Aeg-ajalt tuli põhjapõdrale ohverdada. Tootemit hakati ajapikku jumalikustama.

Omaette küsimus on, kas Meandash (Mientush) on üldsõna või pärisnimi (vt tabel 2). Noor saami rahvusest uurija Jelena Sergejeva on kindlaks teinud, et müüditeisendites kasutatakse põhjapõdra tähistamiseks üldsõnu m'aanndashsh ja koonnt, millest viimane olevat siiski tavapärasem (Sergejeva 1994: 163). Autori arvates võib tavalise nimetuse kasutuselevõtt viidata müüdi muutumisele muinasjutuks, st tabuväliseks tekstiks.

Meandashi nime päritolu selgitamisega pole tõsiselt tegeldud. V. Tsharnoluski 1877. aasta paiku sündinud jutuvestja Pjotr Sarvanov seostas selle saami sõnaga m'änna, mis tähendavat pehmet, ühekahe kuu vanuse põhjapõdra sarvenahka (Tsharnoluski 1965: 62). J. Sergejeva ühendab Meandashi nime mõistega 'pehme, soostunud maa' (Sergejeva 1994: 166). Autor esitab näitena m'aanndashsh jem'n'e, sõna-sõnalt 'pehme maa'. Esitatud näitest ei selgu, kas esimest sõna kasutatakse ka üksinda soo tähenduses või mitte. J. Sergejeva leiab, et müütilise kosmilise soo kujutelmale lähedasi leidub ka sölkuppide ja evenkide mütoloogias. Ometi jääb öeldust tõestuseks väheseks ning oleks vaja lisatõendeid. Uurimist vajavad P. Sarvanovi pakutu ja soo-sõna seosed; loogiliselt ühendavaks lüliks võiks olla mõiste pehme.

Meandash-sõnale tunduvad olevat häälikute poolest lähedased mõnede altai keelte vasted, nimelt evengi ( ehk tunguusi) ja negidaali keele mandaksa 'ühe- kuni kolmeaastane põdrapull' ning jakuudi mandahsa 'kahe-kolme aastane põdrapull' (vt SSTJ 1975: 527). Altai sõnad sobivad saami nimetusega ka tähenduse poolest. Ometi jääb mõistatuslikuks, kus ja millal võis keelekontakt toimuda. Käesolevate ridade autor on püüdnud leida ühist saamide ja tunguuside vahel (Ernits 1990), kuid uurimisbaasi puudumise tõttu Eestis on raske saada veenvaid tulemusi.

J. Sergejeva väitis, et üldnimi m'aanndashsh esineb üksnes kildini keelealal ning samakõlaline pärisnimi veelgi kitsamalt, nimelt alamurdes (Sergejeva 1994: 170). Ent see pole nõnda. Kindlasti esines see metshaldja nimena ka turjalastel (Itkonen 1958: 245). 
Koltadel on sõna meänteis. Soome uurija S. Paulaharju kirjeldab seda saami salapärast metsavaimu pehme olendina, kellelt kütt peab häirimise vältimiseks jahikotta öömajale tulles elamisluba paluma (Paulaharju 1921: 148). Autor jätkab:

Ja siis käib meänteiski vaid tasakesi kohmitsedes ringi, potsatab laest ja tatsab põrandal, liigutab kojas nõusidki, tuleb mõnikord magajale nii lähedale, et teda saaks käega puudutada. Käele tundub ta karvasena, ning nõnda sooja ja pehmena."

Usutavasti on meänteis ja meandash omavahel häälikulooliselt seotud. Selle põhjal võib oletada, et koltadel on sõna põhjapõtra tähistav tähendus kas hääbunud või on see sõna omandatud hoopis mõnelt muult keelerühmalt.

Üldnimi mientush on vististi eelmisest sõnavormist laiema levikuga, kuid A. Genetzi fikseeritud pärisnimedega on asi segasem (tabel 2). Saami keele uurijatel seisab ees mainitud nimetuste keeleajaloolise seose tõestamine.

Koltad kutsuvad põhjapõtra koddi ja mientuz (Paulaharju 1921: 70), kusjuures koddi vastab häälikulooliselt kildini koantile. Ka P. Sarvanov, kelle murdekuuluvus pole selge (ta võib olla kildinlane) vastab V. Tsharnoluski küsimusele meandashitest lausega: "Ah, kas mientushitest?" (Tsharnoluski 1965: 54). Uurija sõnutsi kutsutakse mientushiteks Kintushi pogosti saame, seega turjalasi (Tsharnoluski 1965: 83).

On kindel, et müütiline põhjapõder oli nime poolest tuntud nii kildinitel kui ka turjalastel, üldnime tasandil ehk ka koltadel. A. Minkin arvab ühes artiklis ekslikult, et kohanimi Mjandozero on seotud Meandashiga ja tähendab Meandashijärve (Minkin 1987: 100). Tegu on hoopis ilmselgelt männipuudest johtuva nimetusega!

\section{Ainese kogumise ja uurimise ajaloost}

Saami müüdi pani esmakordselt kirja vene kirjanik Vassili Nemirovitsh-Dantshenko $\left({ }_{2}\right)$ (Nemirovitsh-Dantshenko 1877: 209; teine trükk ilmumisaastata : 362). Loo oli ta üles märkinud 1873. aasta Koola-reisil. Selle ühendus Meandashiga pole selge, kuid üleskirjutus on ainulaadne; seda tajus kirjapanija isegi: Seda uskumust rääkida oli taadil piinlik, samas heitsid ka teised laplased ette: "Miks sa kõneled seda, mida ei kõlba kõnelda?" Ent mõne aasta pärast on see poeetiline pärimus ununenud, nagu on meelest läinud paljud teisedki lood, mis näisid varem laplaste maal kindlalt püsivat.

Tabel 2

Meandash/Mientush koolasaami keeltes

\begin{tabular}{|l|l|l|l||}
\hline Keel: & kolta & kildini & turja \\
\hline Üldnimi & $\begin{array}{l}\text { meänteis 'metsavaim' } \\
\text { (Paulaharju) }\end{array}$ & $\begin{array}{l}\text { meandash 'põhjapõder' (Genetz), } \\
\text { 'isaspõhjapõder' (Itkonen) } \\
\text { m'aanndashsh 'põhjapõder'; } \\
\text { 'pehme' (Sergejeva) }\end{array}$ & --- \\
\hline & $\begin{array}{l}\text { mientuz 'põhjapõder' } \\
\text { (Paulaharju) }\end{array}$ & $\begin{array}{l}\text { ? mientush 'tootempõhjapõder' } \\
\text { (Tsharnoluski) }\end{array}$ & $\begin{array}{l}\text { mientush 'Kintushi saam' } \\
\text { (Tsharnoluski) }\end{array}$ \\
\hline
\end{tabular}




\begin{tabular}{||l||l||l|l||}
\hline Pärisnimi & -- & M'aanndashsh (Sergejeva) & $\begin{array}{l}\text { Meandash 'ulukihaldjas' } \\
\text { (Itkonen) }\end{array}$ \\
\hline & - & $\begin{array}{l}\text { Mintõsh : Meantash (Nuörtsaame) } \\
\text { 'lapi jumalus' (Genetz) }\end{array}$ & $\begin{array}{l}\text { Mientush 'ulukihaldjas' } \\
\text { (Genetz) }\end{array}$ \\
\hline
\end{tabular}

Soome keeleteadlane Arvid Genetz viibis Koolas 1876. aastal ning avaldas "Suomen kuvalehtis" soome keelde tõlgituna loo saami taadi tütarde kosimisest kaarna, hülge ja põhjapõdra poolt (Genetz 1878, 1879a). Asjaomane lugu seondub kahtlemata Meandashiga. Sama muinasjutu avaldas ta Ungari teadusajakirjas ka saami keeles (Genetz 1979b). A. Genetz oli esimene, kes nimetas mainitud kirjelduses ja oma peateoses Mientush/Mintõshi nime (Genetz 1879a, 1891):

Mintõsh, meessoost jumal. Mõnes Jokonga muinasjutus mainitakse Mientushit; see on selline olend, kes vahel ilmub kodustamata põhjapõdrapullina, teinekord muutub põdranahka seljast heites inimeseks ning naib ühe vanapaari noorema tütre, samaviisi kui kaaren ja hüljes naivad vanemad tütred. Meantash-ajk on tema ema.

Esitame nüüd asjaomase muinasloo tervikuna:

Kunagi elasid taat ja eit. Nad elasid, elasid, elasid. Sündis neil kolm tütart. Noh, nad elasid, elasid, elasid. Tuli neile peigmees. Eit magas, tõusis üles, ütles: "Taadike kullake, taat! Kaarna tiivad on konksus (peigmehel)". "Mis sa, eit, räägid? Peigmees on tulnud kui Jumala ingel." Noh, andsid oma tütre naiseks. Siis tuli teine peigmees; eit ütles: "Taadike kullake, taat! Hülge jalad on siruli." "Mida sa, eit, räägid? Peigmees on tulnud kui Jumala ingel." Noh, andsid talle oma tütre naiseks. Tuli kolmaski peigmees; eit ärkas üles, (ütleb): "Taadike kullake, taat! Sarva (3) sarved ripuvad.""Mis sa, eit, räägid? Tuli peigmees nagu Jumala ingel." Sellegi tütre andsid naiseks.

Taat läks oma tütardele külla. Jõudis vanema tütre juurde: tütrel on silmad peast välja kougitud, lapsed kraaksuvad ja karjuvad. Tütar ütles isale: "Mine tagasi, kui kaaren tuleb koju, sööb ta su ära." Noh, asus taat tagasiteele ja põikas keskmise tütre juurde. Jõudis sinna, nägi hülge lapsi koja pealt alla liugu laskmas. Astus kotta; tütrel on teine käsi ära söödud, ise ujub üleni rasvas. Tütar ütleb: "Mine tagasi, hüljes tuleb koju ja sööb su ära." Noh, ta asus tagasiteele; astus, astus ja põikas noorema tütre poole. Jõudis sinna, nägi põhjapõdra lapsi koja pealt alla liugu laskmas, lausuvad: "Vanaisake tuleb." Astus kotta, seal on põhjapõdranahad laiali laotatud. Lapsed hakkasid ema hüüdma: "Isa tuleb!" Tütar ütles isale: "Lähme välja vaatama!" Noh, nad läksid välja, vaatasid: sarvas on tõepoolest tulekul; jõudis koju, tervitas äia, võttis loomanaha seljast, muutus meheks ja hakkas äia kostitama. Äi hakkas tagasi oma eide juurde minema. Väimees andis talle liha kaasa, andis kaasa palju liha: seljarasva, luü̈di, rasviku, pärasoole, jalaliikme, tagajala ning viimaks ka selja tagaosa. Ja jõudiski taat eide juurde, eit hakkas paunast külakosti valitsema ja undiseid küsima.

Kaks asjaomast lugu pani saamidelt kirja Petsamos asuva Borisi ja Glebi kiriku papp Konstantin Shtshekoldin 1887. aastal (Shtshekoldin 1890) ning ühe loo teadmata aastal ameti poolest vist loodusteadlane A. Jashtshenko (Jashtshenko 1892). Vähesel määral on käsitletavast saami ainesest huvitunud hiljem Eestiski uurimisreisil viibinud etnograaf Nikolai Haruzin (Haruzin 1890).

Käesoleval aastasajal on üksikuid Meandashi-lugusid talletanud veel T. I. Itkonen (Itkonen 19311936) ja Erkki Itkonen (Itkonen 1958), ning pärast sõda poola päritoluga uurija Victoria Sienkiewicz-Gudkova (Sienkiewicz-Gudkova 1955), isa poolt eestlastest põlvnev Karjala teadlane Georgi Kert (Kert 1961, 1980, Kert \& Zaikov 1988) ning ungarlane Lászlò Szabò (Szabò 1967). 
Kõige rohkem on Meandashi-lugusid avaldanud kirjutise algusosas mainitud V. Tsharnoluski. Kuna Meandashit peeti müütiliseks ja seega tabuliseks, siis hoiti temaga seotud lugusid ja kombeid võõraste eest salajas. V. Tsharnoluskil õnnestus leida saamidega hingesugulust, mistõttu nood usaldasid ajal, mil muistsed müüdid ja rituaalid olid juba hääbumise äärel ning ristiusu ja hiljem nõukogude võimu mõjul aju tagasoppi surutud, siiski üht-teist oma uskumustest pajatada. V. Tsharnoluski pidi tõotama, et ta neist asjust kellelegi ei räägi. Ta pidas tõotust pensionipõlveni, ajani, mil müütide jutustajad olid manala teele läinud, ning avaldas alles siis sel teemal mitu teost.

\section{Esimene ekskurss Kes oli V. Tsharnoluski?}

Vladimir Tsharnoluski (1894-1969) sündis Peterburis, lõpetas 1914. aastal seal kommertskooli ning jätkas õpinguid mitmes kunstikoolis. Aastail 1921-1926 õppis ta Leningradi Geograafiainstituudis. Põhjalast huvitus ta juba tudengipõlves, 1922. aastal osales ekspeditsioonil, mis uuris neenetsi põhjapõdrakasvatust Kanini poolsaarel.

Enne Teist maailmasõda viibis V. Tsharnoluski mitu korda Koola poolsaare saamide keskel. Sihiks kolhooside rajamine - need hävitasid saami traditsioonilise eluviisi - uuris ta põhjapõdrakasvatust, võttis osa N. Liidu Teaduste Akadeemia Lapi ekspeditsioonist (1927-1928), Vene Geograafiaseltsi Koola ekspeditsioonist (1928-1929) ning oli Põhjapõdrakasvatuse

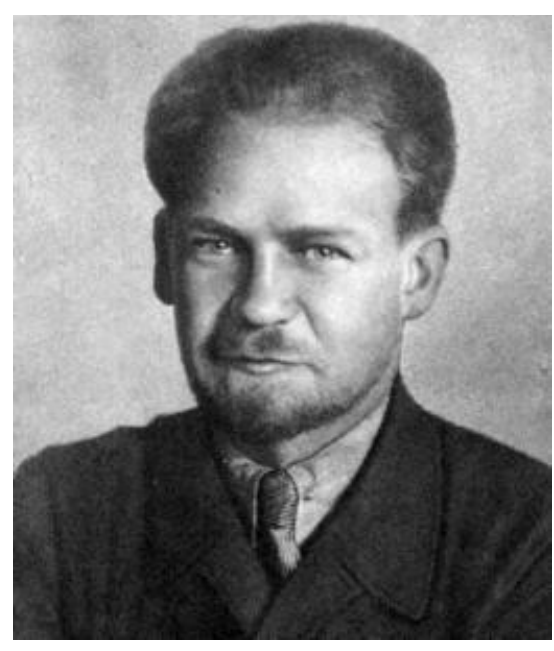

Vladimir Tsharnoluski Instituudi teaduriks (1931-1932). Põhjapõtrade karjatamisest ilmus mitu uurimust. Otsese kutsetöö kõrval pühendus kunstnikuhingeline romantik saami põnevale rahvaluulele ja usundile. Reisid viisid ta Põhja- ja Ida-Koolasse, nimelt kildinite ja turjalaste aladele. Aastail 1936-1938 reisis V. Tsharnoluski Kirjanike Liidu folkloorisektsiooni teadurina Lääne-Koolas Montshegorski kandis.

Pärast Teist maailmasõda töötas V. Tsharnoluski ekspeditsioonide kunstnik-graafikuna. 1958. aastal siirdus ta pensionile ja hakkas kogutud ainestikku avaldama. Järjepanu ilmusid saamiainelised teosed (Tsharnoluski 1962, 1965, 1972). V. Tsharnoluski peamiseks teeneks on see, et ta kogus ja muutis ülihuvitava usundiainese kättesaadavaks.

Mainitud kolmes teoses käsitles V. Tsharnoluski muude tähelepanekute ja reisimuljete kõrval Meandashiga seonduvaid müüte, avaldades venekeelses tõlkes ka nende tekstid. Eestis ilmunud "Skandinaavia kogumikus" ilmus tema sulest artikkel Meandashi kultusega seonduvatest riitustest ja nende sarnasusest tunguusi omadega (Tsharnoluski 1966).

V. Tsharnoluski on ainest kirjanduslikult ilmestanud ja võib-olla isegi liitnud eri teisendeid, mis kahandab oluliselt ta teoste teaduslikku väärtust. Ebatäpsusi on põhjustanud autori nõrk saami keelte valdamine. Mõnikord on saami müüte varasematele teostele viitamata neist laenatud (Autio 1993: 17). Iga kord pole tähele pandud eri keeli ja murdeid. Näiteks on segane loo "Kod'd'-akka" ('Põhjapõdraeit') päritolu: valed on kas kohaandmed (kildini ja turja alal kutsutakse põhjapõtra $k o(a) n n t$ - või eksib uurija nimetusega. Ühte ja sama lugu on ühes raamatus esitatud lühidalt, teises 
aga mitu korda pikemalt (vrd Tsharnoluski 1965: 41-42 ja 1972: 114-117). Asjaomase ainese nappus ei võimalda paraku ulatuslikke võrdlusi, kuid iga Meandashi-teemaline rida on uurimiseks ülitähtis.

V. Tsharnoluski kirjapaneku näitena esitan siinkohal Meandash-põõrre:

Kintushi (*4) tagant, Imandra (*5) tagant, emakese maa sisemusest jookseb välja Meandash - vabalt elav põhjapõder. Meandash-põõrre $(\underset{*}{*})$ on ta nimi, ta on metsiku tshiigari $\left({ }^{* 7}\right)$ algus. Meandashpõõre on elu ja maanurga algus. Meandash-põorrre jookseb ühest paigast teise, väljaspool maa radasid. Tema tee on päikese tee, sinnapoole on ta jookski.

Meandash-põõrre, kuldsarvedega põhjapõder, lendab. Lumivalgena jookseb ta kauge Limandrõ tagant, kauge Norra tagant, lendab otse Kintushi Alajärvele. Määris oma sõra - ei meeldinud talle see maa, ei saanud talle armsaks see vesi. Lippas Siivni (뾰), astus järsule kaljule.

Siin!

Siit paistab kõrge Keiva, Oajmkedzhpoalla $(* 9)$ toitvad maad. Ta jäi seisma, ajas jalad harki, niisutas meie maad, puhkas veidi ja tõusis jalule:

"Mõtted ja mõtisklused kuivatavad mu mõistuse. Heidan pilgu kõikjale kolme-nelja ilmakaarde, kõikjale, kolme-nelja ilmakaarde... Ei tea, kuhupoole minna."

Kõpsatas korra sõraga vastu Siledat Kaljut, sööstis siis kerge hüppega sõrgadega mängeldes edasi. Ta jalad kidisevad, talle kahisevad vastu söödavad rohud ja valged põdrasamblikud. Meandashpõõrre lendab... See on Meandash-põõrre! Oajmkedzhpoalla künkad kerkivad ta jalge all, Suveneem $(* 10)$ tõuseb ta jalge alla.

Talle hakkasid meeldima need mäekünkad. Ta saabus Suvemaale. Pesi sõrgu allikates. Sõi siin, elas siin. Nii sõi kui ka puhkas siin. Siis aga pillas maha oma sarve, kuldse sarve... ja lausus:

"See on tshiigar - Meandashi tundra!" Ja ta võpatas.

Permi hõimude asualalt on leitud arvukalt eelmisel aastatuhandel valmistatud nn permi loomastilis

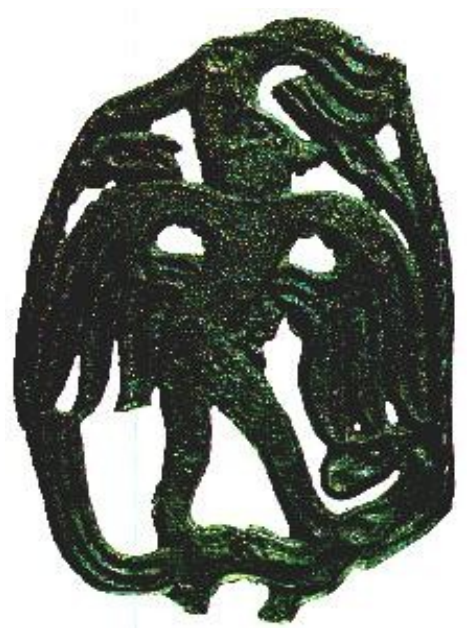
pronksplaadikesi. Nendel on kujutatud kolme ilmasfääri kajastavaid kompositsioone inimese-, põdra-, karu- jt loomalaadsete olenditega. Tõenäoliselt kajastavad nad muinas-soomeugrilaste looduslähedast totemistlikku maailmapilti. V. Tsharnoluski üritas nende motiive võrrelda Meandashi-lugudega. Põhimõtteliselt on taoline kõrvutamine võimalik, kuigi käesoleval juhul subjektiivne, rohkem intuitsioonile kui kainele mõistusele tuginev.

V. Tsharnoluski raamatud on innustanud muistse kaljutaide uurijaid. Akadeemik Aleksei Okladnikov ja Anatoli Martõnov võrdlevad päikesejumalus Meandashi ja talle sarnanevat Siberi kaljupiltidel kujutatud olevust (Okladnikov \& Martõnov 1972: 92, 227-228). 1970- aastatel avastati kiviaja kaljukujutised Koola poolsaarel Põõnne jõe ääres Tshalmne-Varres, mida võiks ehk tõlkida Silmamäeks. Arheoloog Niina Gurina väidab, et Meandashi-müüdi juured peituvadki petroglüüfides (nt Gurina 1992: 15).

Erilist innustust sai Vladimir Tsharnoluski üleskirjutatud lugudest käesoleva kirjutise alguses mainitud Eero Autio. Ta soomendas ning varustas Meandashi-lood asjalike kommentaaridega. Lähemalt

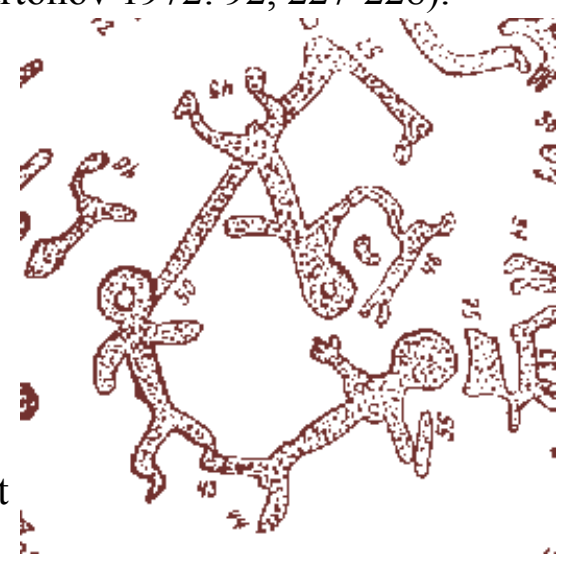


analüüsis ta müütide vastavusi Põhja-Euraasia kaljutaides. Tema arvates ei kujutata sarvedega figuuridel sarvilisi shamaane, vaid hoopis zoomorfseid tegelasi (Autio 1993: 73 jj; 1995). V. Tsharnoluski muinaslood on rootsi keeles avaldanud ja teose asjaliku sissejuhatusega varustanud Kerstin Eidlitz Kuoljok (Tjarnoluskij 1993).

Eero Autio raamatule toetudes on Meandashi taevase Sarvloomaga, sh Sõnni tähtkujuga samastanud (paleo)astronoom Heino Eelsalu (Eelsalu 1995).

Jelena Sergejeva käsitleb esimesena lühidalt Meandashiga seonduva loodususundi põhimõisteid (küttimiskeeld, kultuuriheeros, maagia jt). Ta on V. Tsharnoluskiga ühel arvamusel, et müütilisest põhjapõdrast jutustavat eepikat on esialgu lauldud (Sergejeva 1994).

\section{Meandashi elutsükkel}

Meandashi-lood sisaldavad praegusaja inimese jaoks ebausutavaid tegelasi ja sündmusi. Müütilisest põhjapõdrast on Koola poolsaare saamidelt talletatud lugusid, mida võib käsitleda ühe tervikuna, nimelt Meandashi elutsüklina sünnist surematuseni. V. Tsharnoluski oli seisukohal, et Meandashijutud moodustasid esialgu kindla terviku - eepose, mis aja jooksul ununes ja säilis katketena (Tsharnoluski 1965: 99). Nii see muidugi ei olnud; pigem saaksime rääkida muutuvast ehk dünaamilisest tervikust. Aja jooksul see muutub, juurde tekib (või laenatakse) uusi motiive ja tüüpe; motiivid liituvad omavahel jne.

Meandashi elu saab jagada järgmisteks tinglikeks perioodideks ja vastavateks alateemadeks:

1. Inimeseiga (vt ptk 4.1):

1. poisiiga (4.1.1)

2. meheiga (4.1.2)

2. Kultuuriheerose iga (4.2)

3. Jumalaiga (4.3):

1. äikesejumaluse ohver (4.3.1)

2. päikesejumalus (4.3.2).

Tabel 3

Meandashi-lugude motiivid varianditi ja keeleti

\begin{tabular}{|c|c|c|c|c|c|}
\hline \multirow[b]{2}{*}{ Kogumiskoht } & \multirow{2}{*}{$\begin{array}{l}\text { Elu } \\
\text { esivanematemaal } \\
\text { Inimeseiga }\end{array}$} & \multicolumn{2}{|c|}{ Jumalaiga } & \multirow[t]{2}{*}{ Kultuuriheeros } & \multirow[b]{2}{*}{ Kokku } \\
\hline & & $\begin{array}{l}\text { Äikesejumaluse } \\
\text { ohver }\end{array}$ & Päikesejumalus & & \\
\hline Imandra & 4 & 1 & 1 & - & 6 \\
\hline Kolta & 3 & 2 & - & 1 & 6 \\
\hline Kildin & 5 & - & - & - & 5 \\
\hline Turja & 7 & 1 & 1 & - & 9 \\
\hline Teadmata & 3 & - & - & - & 3 \\
\hline Kokku & 22 & 4 & 2 & 1 & 29 \\
\hline
\end{tabular}


Aegade vältel on ühtekokku avaldatud ligi kolmkümmend Meandashiga seonduvat juttu, sealhulgas kolmandik turjalastelt, muidu on materjal Koola saamidel enam-vähem ühtlaselt levinud. See näitab, et Meandashi tunti kogu Koola poolsaarel. Imandra kandi lugudest kolm on akkala murde alalt, ülejäänud kolme loo keeleline kuuluvus pole teada. Kõige rohkem lugusid on talletatud Meandashi elust müütilisel esivanemate maal (21). Neid on samuti noteeritud kogu Koolast, enim turjalastelt (7). Levikut arvestades on tabelis märgitud kaks päikesejumaluse-loo varianti, sest V. Tsharnoluski on ühe loo pannud kokku kahest eri kandist pärinevast jutust.

\subsection{Inimeseiga \\ 4.1.1. Poisiiga}

Meandashi-jutud algavad varianditi eellooga, mis käsitleb ema viljastumist. Poisiiga kajastavad viis kirjapanekut. Eri variandid kõnelevad sellest ajajärgust erinevalt, mis on loomulik, sest lood pole alguselt päris identsed ning on edasi jutustades tasapidi teisenenud, neile on liitunud uusi osi. Esitame alljärgnevalt juttude kaupa variantide sisu, lühikokkuvõtte ja analüüsi.

Meandashi sünnilugu on vist kõik Koola saamid tundnud. Sellest tõigast lähtuvalt on võimalik, et:

1. lugu tekkis ühissaami perioodil, mil ei eristatud kildineid, turjalasi jne;

2. lugu tekkis ühel saamirühmal ning levis neilt teistele;

3. lugu on tekkis igal rühmal iseseisvalt.

Teisendites on ühtelangevate sündmuste kõrval lahkuminevaid.

\section{Esimene jutt}

"Mjandash-nijd (*12) - Mjandash-deva". V. Tsharnoluski, $1936<$ Pjotr Sarvanov (ka Sorvanov) (snd 1877 paiku - 1943). Imandra, Monntsh. Avaldatud Tsharnoluski 1962: 84-92; 1965: 55-62, Kert 1980: 198-202 (nr. 129).

Sünd ja lapsepõlv. Inimestest eemal maailmas sündis Meandash-neiul põhjapõdrast poeg, kes hakkas peatselt jahil käima.

Põhjapõdrakoda. Poeg ehitas põdranahkadest ja luudest koja ning tahtis abielluda.

Naisevõtt. Ema ujus kolm korda üle verejõe, taadi juurde ja naitis pojale algul selle vanema, hiljem keskmise, siis noorema tütre.

Taaditütarde käitumine. Meandash-neiu käskis taadi pool jalatsid kuivatada. Vanem ja keskmine tütar täitsid erinevalt nooremast tütrest käsu kohusetundetult. Vanem ja keskmine tütar peksid Meandash-neiu vasikatest laste nina veriseks. Noorem tütar hellitas tema lapsi ja punus neile sarvedesse pärjad.

Taaditütarde saatus. Vanem ja keskmine tütar ületasid suuri vaevu ujudes verejõe. Noorem tütar ületas jõe loitsides. Vanema ja keskmise tütre muutis Meandash-neiu tavaliseks kiviks. Noorem tütar sai sarvale naiseks. Neil sündisid lapsed.

Lahkumine naise ja laste juurest. Laps pissis asemele ja põhjapõder põgenes, lapsed kannul. Ema reaktsioon. Kõige nooremale lapsele pakkus ema rinda. Ta hoiatas last karu, hundi ja inimese eest. Seejärel pani ta endale kusese asemenaha keha ümber ja muutus kõigi peurade juhtloomaks (haldjaks). 
Imandra järve äärest üleskirjutatud lugu on suhteliselt terviklik. Käsitletavas teisendis toimuvat sündmustik Mägedes ja vaaradel (*12), soojärvedel ja tundrutes, kus inimesed ei ela ega asu kunagi elama, kuhu nende jalg ealeski ei astu, elavad meandashid. Esialgu võib tunduda, et tegevus toimub reaalsel Lapimaal, ent ometi pole see nii: tegu on müütilise kohaga, mis on surelikule tundmatu, kuigi sarnaneb looduse poolest Koola poolsaarega. Seda maad eristab saamide elualast verejõgi, mida nimetatakse Meandashi jõeks (M'aanndashsh-joGk). See meenutab oma kopsudest lainete ja maksadest kividega elusolendit. Muide, ka soomlastele oli müütiline verejõgi tuntud (Kemppinen 1967: 68). Eks verejõgi ole mõiste, mis jõe kujul eristab, kuid vereolluse poolest ühendab sugulaste territooriume. Muistses loos väljendub saamide horisontaalne universumijaotus.

Meandash-neiu on Meandashi ema, kes esineb noore naisterahvana ühes variandis, teistes lugudes kõneldakse seevastu vanast kogenud teadjanaisest, s.o nõiast vanas soomeugrilises tähenduses. Siinkirjutaja ei tea, kas kujutelm Meandashi ema neiupõlvest on genuiinne või neitsi Maarja pärimusest mõjustatud. Meandash-nijt elab jutustaja arvates inimesena, üksnes verejõge ületades muutub ta põhjapõdralehmaks. Jutustaja sõnutsi ongi ta põhjapõder-naine. Meandashite maal elab ta oma lastega - vanema pojaga, kelle kohta ütleb: Sa oled meandash - põhjapõder, ning nooremate lastega (põhjapõdravasikatega). Esimest kutsutakse käesolevas muinasloos Meandash-paarrniks (*13), millega eristatakse teda teistest, nimetutest õdedest-vendadest. Loo alguse põhjal võiks arvata, et meandashid elavad laial maa-alal, kuid lähemalt tehakse juttu vaid ühest perekonnast.

Meandash-paarrni isa ei mainita. Jutustatakse: Seal elas Meandash-niijt (*11), põhjapõdernaine. Tal sündis vasikas, tähendab poeg. See elas Meandash-neiu juures ning kasvas kiiresti nooreks põhjapõdraks - Meandash-paarrniks. Poeg ei toitunud rohust ega samblikest, nagu põhjapõdrale kohane, vaid ta käis jahil, st harrastas muistsete saamide traditsioonilist eluviisi.

\section{Teine jutt}

"Kod'd' agka - Dikaja staruha". K. Shtshekoldin, $1887<$ M. Fedotov. Kolta, Pattshiesijd. Avaldatud vene keeles Shtshekoldin 1890: 163; Tsharnoluski 1965: 25 (lühendatult); Kert 1980:221 nr 138.

Ema rasestumine. Eit (= nõid) muutus põhjapõdralehmaks ja aeles sarvastega ringi.

Sünd ja lapsepõlv. Ta jäi rasedaks ja sünnitas põhjapõdrast poja.

Ema abistamine. Poeg oli tugev ja peagi hakkas ta aitama ema küttepuude tegemisel. Poeg hakkas vabadusse ihkama. Ema oli nõus, paludes vaid puid varuks tuua. Ta tahtis pojale rinda anda, kuid see keeldus.

Päritolu uurimine. Poeg pani puu raiumisel ema jala paku vahele ja küsis, kes ta isa on. Ema ei kannatanud valu välja ja tunnistas üles, et sarvas.

Lahkumine ema juurest. Siis vabastas poeg ema jala, jättis temaga hüvasti ja põgenes tundrusse.

Käesolev lugu kõneleb üksnes Meandashi poisieast. Anname sõna jutustajale: Väga ammu aega tagasi elas üks eit, kes oli nõid. Kord hakkas tal inimesena igav ning ta moondus põhjapõdraks. Kui kaua oli ta sel

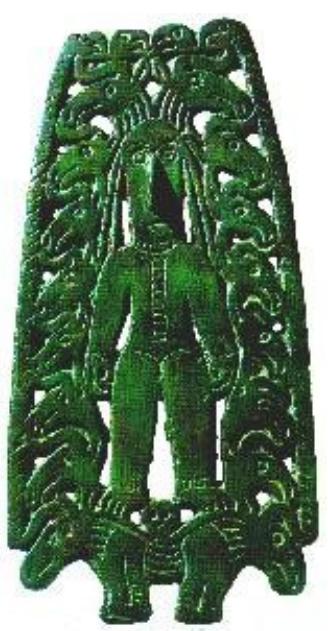
kombel ringi hulkunud, ei oska öelda. Teda sugutasid põhjapõdrad ning ta jäi tiineks. Tuli lõpuks poegimisaeg kätte. Eit kohkus alles sünnituse eel: äkki sünnibki tal põhjapõdravasikas. Ta moondus jälle naiseks. Kuid see ei aidanud ühti - poeg sündiski põhjapõdrana. Noajt (*14) toitis vasikat rinnapiimaga. Poeg kasvas suureks ja hakkas ema puuraiumisel abistama, vedades halge koja 
ette. Ema ja poeg said omakeskis hästi hakkama.

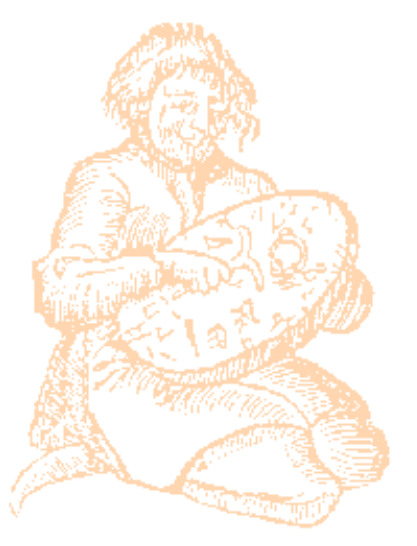

Selles kolta variandis on tegelaseks eakas teadjanaine, kes suutis saavutama kontakti eri universumisfääride vahel. Tema päritolust pole midagi teada, ju ta oli maailma algusest saadik - ka tundru ja põhjapõdrad olid siis olemas - olemas. Naine suutis põhjapõdralehmaks ja taas inimeseks moonduda, mis on ilmses seoses totemistliku mõttelaadiga ning räägib inimeste ja loomade vahelise raja ületamise võimest. Eit jäi sarvast rasedaks ja sünnitas põhjapõdrapoja. Ambivalentne olend - ühelt poolt inimene, teisalt loom - sünnitas looma. Ent põhjapõdrast poegki oli muinasjutuliste võimetega: lapsena tegi ta rasket tööd, aitas emal põletist varuda, rääkis, kasutas riukaid oma päritolu selgitamisel. Taoliste omaduste mainimine viitab, et tegu polnud tavaliste inimeste ja tavalise ajaga, vaid müütilise ajaga, mis oli enne meid (väga атти aega tagasi). Tollal toimus maailmaasjade sünd ja kordaseadmine.

Kui põhjapõdrapoja täiskasvanu-iga oli käes, tahtis ta teada, kes ta isa oli. Saanud oma päritolu teada, lahkus ta ema juurest tundrusse. See oli raja ületamine. Võimalik, et ema piinamine on mõne muinasjututüübi hilisem mõju, mille varal püüti rõhutada piiriületamise raskusi.

Mitmes variandis tahab ema poega imetada, kuid see keeldub, sest aeg on täis ning kohe järgneb eluperioodi vahetus. Kohkumise väljendamine poja sünni puhul võib johtuda konkreetse jutustaja kimbatusest või muudest psühholoogilistest teguritest.

\section{Kolmas jutt}

"Kod'd' agka - Dikaja staruha". K. Shtshekoldin, $1887<$ M. Fedotov. Kolta, Pattshiesijd. Avaldatud vene keeles Shtshekoldin 1890: 163; Tsharnoluski 1965: 25 (lühendatult); Kert 1980: nr 138.

Ema rasestumine. Eit (= nõid) muutus põhjapõdralehmaks ja aeles sarvastega ringi.

Sünd ja lapsepõlv. Ta jäi rasedaks ja sünnitas põhjapõdrast poja.

Ema abistamine. Poeg oli tugev ja peagi hakkas ta aitama ema küttepuude tegemisel. Poeg hakkas vabadusse ihkama. Ema oli nõus, paludes vaid puid varuks tuua. Ta tahtis pojale rinda anda, kuid see keeldus.

Päritolu uurimine. Poeg pani puu raiumisel ema jala paku vahele ja küsis, kes ta isa on. Ema ei kannatanud valu välja ja tunnistas üles, et sarvas.

Lahkumine ema juurest. Siis vabastas poeg ema jala, jättis temaga hüvasti ja põgenes tundrusse.

Asjaomases variandis on inimnaine mitteinimese (= looma) abikaasa. Nappide sõnadega esitatud sünniloos ei ole poja kuuluvust märgitud, kuid hilisematest sündmustest selgub, et tegu on inimpõhjapõdraga. Ka selles loos (vrd esimese jutuga) viidatakse nende küttimistavale.

\section{Neljas jutt}

"Skazka pro pyzhika-ditja". V. Tsarnoluski, $1927<$ Varvara

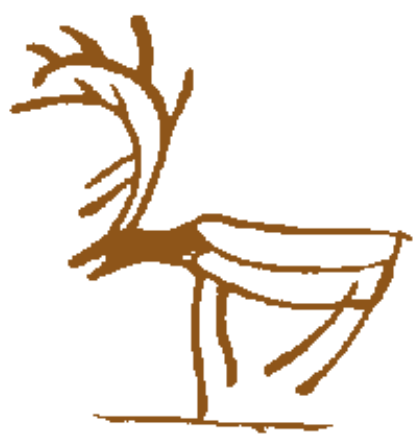

Kuropteva (snd u 1867). Turja, Jovkõj. Avaldatud 
Tsharnoluski 1965: 29, Kert 1980:221-222 nr 139.

Ema rasestumine. Naisterahvas aeles põhjapõtradega ringi, jäi rasedaks.

Sünd ja lapsepõlv. Naine sünnitas inimpoja.

Lahkumine ema juurest. Poeg muutus põhjapõdrakarja nähes põhjapõdraks ja põgenes koos sellega tundrusse.

Ema reaktsioon. Ema kurvastas ja needis poja: kuuli eest see pääse eales. Sellest ajast peale algas põhjapõdrajaht.

Jutustaja kõneleb: Elas kord naine, kes polnud sugugi vana, vaid üpris noor. Ta elas põhjapõtrade seas ja aeles sarvasega. Tal sündis poeg.

Poeg sai kolmeaastaseks. Ühel päeval tuli põhjapõdrakari naise koja juurde. Päris karja keskel oli aga sarvas - põhjapõdrapull. Naine vaatas karja, ise aga mõtles: "Ei tea, kas ka minu sarvas on nende seas?"

Vaevalt oli see mõte läbi pea vilksatanud, kui kari sööstis koja juurest eemale, sarvas kõige ees. Kõik jooksid minema.

Naisel oli poeg rinna otsas, väike põhjapõdrapoeg. See moondus vasikaks, hüppas ema sülest maha ja tormas tundrusse teiste kannule. Ema jäi üksi. Ta hü̈̈ab ja hõikab oma kallist poega, nutab teine ja kurvastab üüratul kombel. Viimaks naasis poeg ema juurde ja lausus: "Ema, ema! Sinu süles oli küll hea olla, kuid põhjapõtrade seltsis on toredam."

"Mille poolest on sul seal toredam, armas lapsuke?" küsis ema.

"Sarved tinisevad, sõrad kidisevad, vastu tuult on omatahtsi nii tore joosta."

Ema pidi taas üksi jääma. Ta hakkas nutma ja lausus: "Kallis lapsuke, minu juurest läksid sa küll minema, kuid kuuli eest ei pääse!"

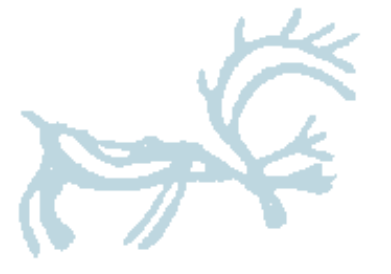

Sellest ajast peale hakatigi põhjapõtru küttima, varem seda ei tehtud.

Selles loos märgib müütilist kronotoopi vaid sõna kord umbmäärase minevikuga. Meandashi ema elas esialgu põhjapõtrade seas, hiljem veetis elupäevi koos pojaga kojas, neist eraldi, kuid ilmselt samas ilmasfääris, sest mingitest piiridest pole juttu.. Mõnes teisendis on ema põhjapõdraga abielus, mõnes ainuüksi ameleb põhjapõtradega.

Vladimir Tsharnoluski ise seletas selle loo teket järgmiselt: Muinasloost õhkus kauge mineviku hõngu. Väga ammustel aegadel kehtis saamide esivanematel nähtavasti keeld põhjapõtru küttida. Arusaadaval põhjusel ei kartnud ulukid seepärast inimesi. Kui mõnikord leiti karjast maha jäänud vasikas, siis võtsid selle naised oma hoole alla, teda isegi rinnapiimaga toites. Taolisi juhte olen sattunud kuulma veel tänapäevalgi. Rinnapiima saanud vasikas muutus taltsaks. Sääseperioodil, st ajal, mil leidus ohtrasti sääski, hoidusid põhjapõdrad inimeste lähedusse. Kolde- ja ahjusuitsus leidsid loomad varjupaika sääskede ja kihulaste - kogu põhjala elanike nuhtluse eest. Sääseperioodi möödumisel sööstsid põhjapõdrad inimestest kaugemale, kodustatud vasikas kannul.

Ma ei taha sugugi väita, et just selle tava tõttu on tekkinud eespool esitatud muinasloo süzhee. Asi on muidugi palju keerulisem, kuid mõneti on see tava kindlasti mõjustanud.

Turja teisendis ei kõnelda midagi ema moondumisest ega poja töödest. Viimane muutus põhjapõdraks alles siis, kui kari, kelle hulgas oli ka ta isa, lähenes nende kojale. See sümboliseerib aja täitumist. 
Turja ja kolta teisendite vahel on ilmne sugulus, vähemalt ema ringiaelemise motiivi poolest. Turja teisendis esineb etioloogiline seletus põhjapõtrade küttimise tavale.

Vormel "polnud sugugi vana, vaid üpris noor" - kui see on rahvaehtne - väljendab hilise aja jutustaja kahtlusi ja kompromissi leidmist. Võib-olla esines varem ka turja teisendis eakas teadjanaine, kuid jutustajal oli teda võimatu kujutleda sünnitaja rollis.

\section{Viies jutt}

T. I. Itkonen, 1927 < Mikko Fedotov (snd u 1907). Kolta, Pattshiesijd. Avaldatud saami ja soome keeles Itkonen 1931-1936: 70-72.

Lahkumine naise ja laste juurest. Lapsed tegid asemenaha märjaks ja põhjapõder-inimene põgenes igaveseks.

Ema abistamine. Poeg oli tugev ja aitas ema puude tegemisel.

Päritolu uurimine. Poeg tahtis kogu aeg teada oma päritolu. Kord pani ta puu raiumisel ema jala paku vahele ja küsis, kes ta isa on. Valu tõttu tunnistas ema, et sarvas. Siis vabastas poeg ta jala.

Lahkumine ema juurest. Seejärel põgenes poeg põhjapõdraks muutunult tundrusse.

Ema reaktsioon. Ema hoiatas poega küttide eest.

Siinpuhul on liitunud kaks lahkumistüüpi, nimelt emakodust lahkumine ning põgenemine naise ja laste juurest. Ka see kolta variant sisaldab ema pinnimist ja tundrusse lahkumist. Alles lahkumise eel muutub poeg põhjapõdraks. Lahkumisega kaasnevad ema hoiatussõnad.

\section{Kokkuvõte poisiea-lugude kohta}

Meandashi lapsepõlvest on ühtekokku teada viis teisendit (tabel 4). Variantide vähesus võimaldab enamasti vaid pelki konstateeringuid.

Variandid koosnevad 2-5 motiivist. Kõige täiuslikumad on kolta teisendid. Turja loos leidub 5 motiivi ning ainulaadne müüdi seletus. Iga motiiv esineb 2-5 korda. Poja lahkumise motiiv leidub kõigis teisendeis. Meandashi sünnist kõneldakse kogu Koolas, kuid kahjuks on need enamasti ühekordsed kirjapanekud, vaid koltade teisendid on motiividelt üpris sarnased. Imandra-kandi jutustaja keeleline kuuluvus on ebaselge. Motiiv sarvase sünnist võiks osutada kildinite ja akkalaste variantide lähedasele sugulusele.

Meandashi ema kohta leidub juttudes kolm seletust:

1. ta oli neitsi (Imandra-äärses teisendis),

2. ta oli inimesena põhjapõdraga abielus (esineb kildini teisendis),

3. ta muutus põhjapõdralehmaks sarvastega ringi aeledes (koltadel ja turjalastel).

Seega näib, et ema päritolu käsitlevad eri saami hõimud erinevalt. Teisendite vähesus ei luba öelda, kas see oli nii juba algselt. 
Tabel 4

Meandashi lapsepõlve motiivide levik

\begin{tabular}{|l|l|l|l|l|l|l||}
\hline Motiiv & Imandra-kant & Kolta I variant & Kolta II variant & Kildini & Turja & Kokku \\
\hline Ema rasestumine & - & + & - & + & + & 2 \\
\hline Sarvase sünd & + & + & - & + & - & 2 \\
\hline Ema abistamine & - & + & + & - & - & 2 \\
\hline Päritolu uurimine & - & + & + & - & + & 2 \\
\hline Poja lahkumine & + & + & + & - & + & 3 \\
\hline Ema reageering & + & - & + & 3 & 4 & 16 \\
\hline Kokku & 3 & 5 & 4 & + & + & 5 \\
\hline
\end{tabular}

Ema abistamise ja päritolu uurimise motiiv esineb ainuüksi koltadel. Seejuures on poja hoiatamine võetud ilmselt üle Meandashi perekonnast lahkumise loost. Poja lahkumine esineb kõigis teisendis, kuid on kahel juhul (imandra, kildini) laenatud just äsja mainitud teise lahkumise loost.

Läheb edasi...

\section{Kirjandus}

Autio, E. 1993. Kultasarvipeura ja sen klaani: Totemisia taruja ja menoja Kuolan niemimaalta. Jyväskylä.

Autio, E. 1995. The Possibility of Totemism in the Interpretation of the Ancient Rock-Pictures in the Baltic Area. Castrenianumin toimitteita. 49, 1k 180-202.

Eelsalu, H. 1995. Rahvaluule mõistatuslik valge põder. Keel ja Kirjandus. 9, 1k. 611-616.

Ernits, E. 1990. O drevnih kontaktah mezhdu saamami i tunguso-mandzhurcami. Materialy VI

Mezhdunarodnogo kongressa finno-ugrovedov. Moskva. T. 2, lk 236-238.

G[enetz], A. 1878, 1879a. Matkamuistelmia Venäjän Lapista. Suomen kuvalehti. 141, 1k 328-330;

$145,1 \mathrm{k} .10-11$.

Genetz, A. 1879b. Orosz-Lapp nyelvmutatványok: Máté evangélioma és eredeti textusok.

Nyelvtudományi Közlemények. Budapest. 15, 1k 74-152.

Genetz, A. 1891. Kuolan Lapin murteiden sanakirja ynnä kielennäytteitä. Helsinki (Bidrag till kännedom af Finlands natur och folk; 50).

Gurina, N. N. 1992. Naskal'nyje izobrazhenija Kol'skogo poluostrova. Rossiiskaja arheologija. 3, 1k 5-17.

Haruzin, N. 1890. Russkije lopari. Moskva (Izvestija Obshtshestva jestestvoznanija, antropologii i etnografii; 66).

Itkonen, E. 1985. Kildinlappische Sprachproben. Helsinki (Suomalais-ugrilaisen seuran 
toimituksia; 191).

Itkonen, T. I. 1931-1936. Koltan ja kuolanlappalaisia satuja: I-II. Koltalaisia ja kildiniläisiä satuja, koonnut T. I. Itkonen; III. Jokongalaisia satuja, koonnut D. E. D. Europaeus. Helsinki (Suomalaisugrilaisen seuran toimituksia; 60).

Itkonen, T. I. 1958. Koltan- ja kuolanlapin sanakirja. Osa 2. Helsinki (Lexica Societatis FennoUgricae; 15).

Jashtshenko, A. 1892. Neskol'ko slov o Russkoi Laplandii. Etnografitsheskoe obozrenie. 1, lk 1037.

Kemppinen, I. 1967. Haudantakainen elämä karjalaisen muinaisuskon ja vertailevan uskontotieteen valossa. Helsinki (Karjalan Tutkimusseuran julkaisuja; 1).

Kert, G. M. 1961. Obrazcy saamskoi retshi: Materjaly po jazyku i fol'kloru saamov Kol'skogo poluostrova: (Kil'dinski i iokangski dialekty. Moskva-Leningrad.

Kert 1980. Saamskije skazki. Murmansk.

Kert, G. M. \& Zaikov, P. M. 1988. Obrazcy saamskoi retshi. Petrozavodsk.

LL 1987. Loomade elu. Kd. 7: Imetajad /Toimetanud L. Poots. Tallinn.

Minkin, A. A. 1987. O saamskih etnotoponimah. Etnitsheskaja toponimija. Moskva, lk 92-103. Nemirovitsh-Dantshhenko, V. I. 1877. Strana holoda: Skazki i pesni loparei. Sankt-Peterburg. Nemirovitsh-Dantshenko, V. I. 1881. Loparskaja zemlja. Zhivopisnaja Rossija. Sankt-Peterburg. T. 1, tsh. 1, 1k 163-184.

Oborin, V. A., Tshagin, G. N. 1988. Tshudskie drevnosti Rifeja: Permski zverinyi stil'. Perm'. Okladnikov, A. P., Martynov, A. I. 1972. Sokrovishtsha tomskih pisanic. Moskva.

Paulaharju, S. 1921. Kolttain mailta: Kansatieteellisiä kuvauksia Kuollan-Lapista. Helsinki.

Sergejeva, E. 1994. Kuolansaamelaisten folkloresta - peuramies. Johdatus saamentutkimukseen. Helsinki, lk 163-170 (Tietolipas; 131).

Shtshekoldin, K. 1890. Loparskije skazki, legendy i skazanija, zapisannyje v Pazreckom pogoste, pogranitshnom s Norvegiej. Zhivaja starina. 2, Lk 158-168.

Sienkiewicz-Gudkova, V. 1960. Ustinja Pavlovna Tarunova lapi muinasjutte. Emakeele Seltsi aastaraamat. Tallinn. Kd. 6, 1k 210-219.

SSTJ 1975. Sravnitel'nyi slovar' tunguso-man'tshzhurskih jazykov. T. 1. Leningrad.

Tsharnoluski, V. 1962. Saamskije skazki. Moskva.

Tsharnoluski, V. V. 1965. Legenda ob olene-tsheloveke. Moskva.

Tsharnoluski, V. V. 1972. V kraju Letutshjego kamnja: Zapiski etnografa. Moskva.

Tabayíalgusone 


\section{Kommentaarid}

1 Keiva (saami Keiiva, Keivõ, seostub ehk eesti ja soome sõnaga kivi) - Koola poolsaare põhjaosas Jovkõj ja Põõnne vahel kirde-kagu suunas kulgev ligikaudu 200 km pikkune ja kuni 397 m kõrgune mäeseljak. Jovkõj küla on mainitud esmakordselt 1575. aastal; 1938. aastal elas seal ühtekokku 233 inimest.

Põõnne on 410 kilomeetri pikkune Koola poolsaare keskosas läänest itta voolav ja Valgesse merre suubuv jõgi.

2 Vassili Nemirovitsh-Dantshenko (1849-1936) - vene kirjanik, kes on rohkesti avaldanud sõjaromaane ja reisikirju, sh "Solovetsid" (1874), "Külmuse maal" (1877). Viimane kajastab autori Koola-reisi. Kirjanik oli tuntud teatritegelase Vladimir Nemirovitsh-Dantshenko (1858-1943) vanem vend.

3 Sarvas (saami sar'ves', saarves) - üle kolme aastane isane põhjapõder. Siinkirjutaja on võtnud selle sõna kasutusele soome sarvase eeskujul.

4 Kintush (vene keeles Kamensk) - saami küla, mis paikneb Põõnne jõe keskjooksul, rajati kas XVII sajandi lõpul või järgmise algul. 1929. aastal moodustati seal põhjapõdrakolhoos. Aastail 1933-1934 aeti enamik Kintushi elanikke 8 km kaugusel olevasse Tshalmnõ-Varri. 1939. aastal elas Kintushis vaid 13 saami.

5 Imandra (saami Ävver) - järv Koola poolsaare kaguosas (pindala üle 800 km², suurim sügavus 67 $\mathrm{m})$.

6 Meandash-põõrre - V. Tsharnoluski materjalide põhjal saamide põhjapõdrakujuline päikesejumalus. Viimasele sõnaosisele omistab ta tähenduse 'hea'; T. I. Itkoneni sõnaraamatu järgi tähendab Meäntazh-bõõrre lihtsalt 'põhjapõdrasaaki' (Itkonen 1958: 245).

7 Tshiigar (kildini tshiigar, turja tshiigr; vene kegora) - põdrasamblikuga kaetud karjamaa; põhjapõtrade karjamaa.

8 Siivn (saami Siivn, vene Sõivan) - mägi Põõnne jõe põhjakaldal Kintushi kandis.

9 Oajmkedzhpoalla - kõrgustik, millel paiknes kaks relikti ja kaks teetähist. Minevikus peeti neid seitadeks (V. Tsharnoluski). Seit (saami seiit, siit) - püha kivi; inimesesarnased kivid seostati esivanemate kultusega, ülejäänud (ka kivihunnikud või - püramiidid, nn hurrid) aga toimisid küttide-kalastajate kaitsjatena; seidadele toodi ohvriande.

10 Suveneem (vene Letni Navolok) - Koola poolsaare idaosa (V. Tsharnoluski teatel).

11 Niijt (saami niijt) - neiu; tütar.

12 Vaar (saami vaarr') - metsaga kaetud laugete nõlvadega mägi; mets. 
13 Paarrn (saami paarr'n; põlvneb vene sõnast paren') - poiss, noormees.

14 Noajte (saami keeles) - nõid, teadjamees (-naine), shamaan.

Jooniste allkirjad

1. Koola poolsaare asulaid

2. Vladimir Tsharnoluski (1894-1969).

3. Meandashi-lood on kasutamist leidnud permi loomastiilis pronksnaastude sisu tõlgendamisel. Tiivuline inimpõder sisalikulaadsel olendil. VII-VIII sajandist. Oborin, Tshadin 1988 järgi.

4. Põhjapõdramüüti kajastavad uurijate arvates ka Põõnne jõe kallastel leiduvad neoliitilised kaljuraiendid. Gurina 1992 järgi.

5. Pronksnaast Permi oblastist. Inimlaadne olend kahepäisel loomal (põdral?) on ümbritsetud põdraja greifipeadega. VII-VIII sajandist. Oborin, Tshadin 1988 järgi. Tõenäoliselt oleks V. Tsharnoluski selle nimetanud "Meandashi ema sarvastega ringi aelemas".

6. Lapi nõid loitsimas. J. Schefferuse (1674) järgi.

7. Põhjapõdrakujutis saami shamaanitrummil. Kas metsik või kodustatud?

8. Põhjapõdrakujutis saami shamaanitrummil. Kas taeva või manala loom? 